\title{
Combining ability studies of biochemical traits in intra and interspecific crosses of brassica
}

\author{
Amir Sohail ${ }^{1 *}$, Sikandar Shah ${ }^{1}$, Farhatullah ${ }^{1}$, Iftikhar Hussain Khalil ${ }^{1}$, \\ Tanvir Burni ${ }^{2}$ and Fazal Hadi ${ }^{2}$ \\ 1. Department of Plant Breeding and Genetics, The University of Agriculture, Peshawar, Khyber Pakhtunkhwa- \\ Pakistan \\ 2. Department of Botany, University of Peshawar Khyber Pakhtunkhwa-Pakistan \\ *Corresponding author's email: amirsohail@aup.edu.pk
}

Citation

Amir Sohail, Sikandar Shah, Farhatullah, Iftikhar Hussain Khalil, Tanvir Burni and Fazal Hadi. Combining ability studies of biochemical traits in intra and interspecific crosses of brassica. Pure and Applied Biology. Vol. 7, Issue 2, pp840-852. http://dx.doi.org/10.19045/bspab.2018.700103

\begin{tabular}{llll}
\hline \hline Received: 30/03/2018 & Revised: 08/06/2018 & Accepted: 21/06/2018 & Online First: 01/07/2018 \\
\hline \hline
\end{tabular}

\section{Abstract}

An experiment was carried out at Khyber Pakhtunkhwa Agricultural University, Peshawar during 2016-2017 to study intra- and inter specific brassica crosses for computing combining ability The experimental material comprised of six Brassica napus parental genotypes i.e. N-502, N-510, N$514, \mathrm{~N}-531, \mathrm{~N}-533, \mathrm{~N}-547$ crossed with three testers i.e. one each of B. napus (N-532), B. juncea (J-109), and B.campestris (C-118) in line $\mathrm{x}$ tester fashion. Data were recorded in parental lines and $\mathrm{F}_{1} \mathrm{~S}$ on erucic acid, glucosinolate, protein, oleic acid, linolenic acid content and oil yield. Significant differences $(\mathrm{p} \leq 0.01)$ were observed in all genotypes for all of the traits. Mean squares for combining ability showed that female parental lines were significantly different for erucic acid, while, male parental lines (testers) were significantly different for oil content, oleic acid, erucic acid and oil yield. General (GCA) and Specific (SCA) combing ability effects showed that only 13 traits were controlled by additive genes, while remaining traits showed non-additive effect. The GCA effects of female parental lines were greater for protein content, while for male parental lines it was greater for remaining traits as compared to SCA effects. Among female parental lines, desirable GCA effects were exhibited by line N-533 protein content and oleic acid content. Line N-531 showed desirable values for linolenic acid. Line N-502 was best general combiner for protein and erucic acid content. Among testers, N-532 exhibited desirable GCA for oil, glucosinolate, oleic acid, erucic acid content and oil yield plant ${ }^{-1}$. Maximum SCA effects was recorded for linolenic acid. Among $\mathrm{F}_{1}$ hybrid (N-533 x C-118) and (N-510 x J-109) expressed the maximum desirable SCA effects. The cross "N-533 x C-118" was the best specific combiner for all the traits studied followed by "N-547 x C-118" which proved good specific combiner for most of the traits including oli yield plant ${ }^{-1}$

Keywords: Brassica; Biochemical traits; Combining ability; Intra and inter specific crosses

\section{Introduction}

Pakistan has been facing edible oil scarcity for years regardless of unassuming progress made in agricultural sector [1]. Local production of edible oil shared only $23 \%$ (662 thousand tons) of total country's need, 
while the remaining $77 \%$ was met through imports by spending huge foreign exchange (i.e. 2.0 billion US\$). Cotton seed and brassica (different species of genera Brassica) are the major contributors in local oilseed production. Of more than 300 cultivated species of Brassica, B. rapa, $B$. juncea and $B$. napus are major sources of edible oil in the county. The production of rapeseed and mustard in 2016-17 decreased by 11.3 percent compared to 2014-15 [2]. Non-availability of better-adapted genotypes and decrease in area under oilseed crops could be the main reasons for lower edible oil production in the country [3]. The need for increased yield is felt because the country's population is increasing and the demand for oil in the country is expected to grow by 3 $4 \%$ per year [4]. Brassica belongs to family Brassicaceae also known as cruciferae, the mustard family. Family Brassicaceae includes 3709 species and 338 genera [5], and is one of the ten most economically important plant families [6]. The genus brassica is an important member of family cruciferae and consists of 159 species, including a number of wild species that are potential sources of novel and economically important distinctiveness [7]. The genus brassica includes several economically important crops such as turnip rape (B. rapa), Indian mustard (B. juncea) and black mustard (B. nigra) [8]. According to $\mathrm{U}$ triangle (U, 1935) B. nigra (BB), B. oleracea (CC), and $B$. rapa (AA) are the diploid species, while $B$. carinata (BBCC), B. juncea (AABB) and $B$. napus (AACC) are amphidiploids which resulted from hybridization between corresponding pairs of the diploid species [9]. In Pakistan during the year 2016-17, total cultivated area under rapeseed was 194 thousand hectares, producing 168 thousand tons of seed, which yielded 50 thousand tons of oil [2]. The yield of brassica in Pakistan is quite lower than its potential. There are many factors responsible for lower yield, but the most important one is the non-availability of high yielding varieties. It is, therefore, imperative to develop improved varieties of oilseed brassica [10].

Rapeseed (B. napus L.) oil ranks third following soybean and palm oil around the world. Apart from straight human and animal consumption, industrial uses include the manufacture of rapeseed oil and converting biomass to bio-energy. Beside its use for food, feed and industrial purposes, rapeseed oil is also used for metilester, which is important component for biodiesel production [11].

The phenomenon of heterosis of $F_{1}$ hybrids can also imitate specific combining ability (SCA) and general combining ability (GCA) of parental lines [12]. The heterosis component is largely dependent on dissimilar parents with good general combining ability (GCA). In practical heterosis breeding, it is necessary to choose combinations with high degree of specific combining ability (SCA) as well as parents with high general combining ability GCA [13]. Identifying such parental combinations with strapping heterosis for yield is one of the most important steps in the development of new cultivars $[12,14,15]$.

General and specific combining ability effects are imperative indicators of the impending of inbred lines in hybrid combinations. General combining ability (GCA) is the average performance of a line in hybrid combinations, and specific combining ability (SCA) is the deviation of certain cross from the average performance of the lines [16]. The relative importance of additive (GCA) and non-additive (SCA) gene actions within a breeding population is vital to determine that which breeding procedure will efficiently improve the performance of the characters of interest [17]. Combining ability concepts are the basic tackle for improved production of crops in the form of $\mathrm{F}_{1}$ hybrids. For faster advances in breeding it 
is necessary to know variability, heterosis and combining ability of breeding material, i.e., modes of inheritance of certain trait [18]. The objectives of this study was to evaluate the performance of brassica hybrids for combining ability effects for biochemical parameters.

\section{Materials and methods}

The research work was conducted at New Developmental Farm, Khyber Pakhtunkhwa Agricultural University Peshawar during 2016-17 to study combining ability in brassica hybrids crossed in line $\mathrm{x}$ tester mating design.

\section{Experimental materials}

The experimental materials were comprised of nine genetically diverse genotypes of brassica. Six genotypes which were used as female parent were of B. napus i.e., ( $\mathrm{N}-502$, $\mathrm{N}-510, \mathrm{~N}-514, \mathrm{~N}-531, \mathrm{~N}-533$ and N-547) and three genotypes used as testers were $B$. napus (N-532), B. juncea (J-109) and B. campestris (C-118) (Table 1). These genotypes were crossed in line $\mathrm{x}$ tester mating design to produce their respective $\mathrm{F}_{1}$ hybrids (Table 2).

Table 1. List of brassica genotypes used as a parent collected from different regions of Pakistan

\begin{tabular}{|c|c|c|}
\hline Parents & Species & Collection site \\
\hline Female Parents & & Rawalakot, AJK \\
\hline N-502 & B. napus & Okara, Punjab \\
\hline N-510 & B. napus & Rajanpur, Punjab \\
\hline N-514 & B. napus & Diamer, Gilgit Baltistan \\
\hline N-531 & B. napus & Swabi, Khyber Pakhtunkhwa \\
\hline N-547 & B. napus & Haripur, Khyber Pakhtunkhwa \\
\hline Male Parents & B. napus & Rawalpindi, Punjab \\
\hline N-532 & B. napus & USA \\
\hline J-109 & B. juncea & Islamabad \\
\hline C-118 & B. campestris & \\
\hline
\end{tabular}

Table 2. List of parents (Lines and Testers) along with their respective inter and intraspecific hybrids studied in this experiment

\begin{tabular}{|c|c|c|c|}
\hline Female Parents & \multicolumn{3}{|c|}{ Male parents/Testers (intra and inter-specific crosses) } \\
\hline Lines & Intraspecific crosses & Interspecific crosses & Interspecific crosses \\
\hline B. napus & $\mathrm{N}-532($ (B. napus) & C-118 (B. campestris) & $\mathrm{J}-109$ (B. juncea $)$ \\
\hline $\mathrm{N}-502$ & $\mathrm{~N}-502 \times \mathrm{N}-532$ & $\mathrm{~N}-502 \times \mathrm{C}-118$ & $\mathrm{~N}-502 \times \mathrm{J}-109$ \\
\hline $\mathrm{N}-510$ & $\mathrm{~N}-510 \times \mathrm{N}-532$ & $\mathrm{~N}-510 \times \mathrm{C}-118$ & N-510 x J-109 \\
\hline $\mathrm{N}-514$ & $\mathrm{~N}-514 \times \mathrm{N}-532$ & $\mathrm{~N}-514 \times \mathrm{C}-118$ & N-514 x J-109 \\
\hline $\mathrm{N}-531$ & $\mathrm{~N}-531 \times \mathrm{N}-532$ & $\mathrm{~N}-531 \times \mathrm{C}-118$ & N-531 x J-109 \\
\hline $\mathrm{N}-533$ & N-533 x N-532 & $\mathrm{N}-533 \times \mathrm{C}-118$ & $\mathrm{~N}-533 \times \mathrm{J}-109$ \\
\hline N-547 & N-547 x N-532 & N-547 x C-118 & $\mathrm{N}-547 \times \mathrm{J}-109$ \\
\hline
\end{tabular}

\section{Field Layout}

The $F_{1}$ hybrids along with their parents were evaluated in Randomized Complete Block (RCB) design with three replications. Each replication comprised of 27 entries $\left(18 \mathrm{~F}_{1} \mathrm{~S}+\right.$ 9 parents). Three rows were allotted to each entry, where each row was 5 meter in length. The plant to plant and row to row spacing was 30 and $60 \mathrm{~cm}$ respectively. All cultural practices like fertilizer, irrigation and weeding were carried out according to the standard recommendations. 


\section{Biochemical Parameters}

Biochemical analysis of these parents and their respective crosses was conducted at Biochemical Lab, Crop Breeding section of NIFA-Peshawar using Near Infra-Red Spectroscopy System FOSS 6500 equipped with ISI version 1.02a software of Infra Soft International according to the manufacturer's protocol. Biochemical parameters used in current study were viz. Oil content, Erucic acid content, Glucosinolate content, Protein content, Oleic acid content, Linolenic acid content.

\section{Statistical Analysis}

To estimate significant differences in parents and crosses. The data was subjected to analysis of variance technique as per design used to calculate $F$ values among the genotypes including crosses and parents. The line $\mathrm{x}$ tester analysis was to perform analysis of variance as per design used to calculate $F$ values among the genotypes including crosses and parents. General combining ability (GCA) and specific combining ability (SCA) were estimated according to [19].

\section{Results}

Oil content (\%)

Analysis of variance of oil content showed significant genetic differences $(\mathrm{p}<0.01)$ among parents and their respective $\mathrm{F}_{1}$ hybrids (Table 3). Overall parental and $F_{1}$ mean was $45.2 \%$ and $45.0 \%$ respectively (Table 4 ). The GCA effects for oil content ranged from 1.01 to 0.64 . Four of the lines demonstrated positive GCA effects. N-533 (0.64), N-510 (0.61), N-547 (0.36), and N-514 (0.16) had positive GCA effects. N-531 (-1.01) and N502 (-0.76) manifested GCA in negative direction. GCA effects of testers for this trait were in a range of -1.36 to 1.81 . The only positive GCA value was given by $\mathrm{N}-532$, while remaining two testers showed GCA effects in a negative direction (Table 5). Results of specific combining ability effect for oil content revealed that out of total eighteen $F_{1}$ hybrids, as many as eight crosses showed desirable values. Range of SCA effect among all the crosses was found to be -1.77 to 1.81 , where the maximum negative value was recorded for a intraspecific cross $(\mathrm{N}-547 \times \mathrm{N}-532)$ while desirable positive value was shown by interspecific cross of $B$. napus and B. juncea (N-547 x J-109) (Table 6). Amid interspecific hybrid of B. napus and B. campestris, SCA effect was in a range of 1.34 to 1.38 . Desirable positive value was exhibited by thee interspecific crosses of $B$. napus and B. campestris viz. N-533 x C-118 (1.38), N-514 x C-118 (0.39), and N-502 x C118 (0.28), while remaining crosses showed negative SCA value for this trait. Amid interspecific hybrid of $B$. napus and $B$. juncea, SCA effect was in a range of -1.64 to 1.81. Desirable positive value was exhibited by two interspecific crosses of $B$. napus and B. juncea viz. N-547 x J-109 (1.81), N-531 x $\mathrm{J}-109$ (1.15), while remaining crosses showed negative SCA value for this trait. Among intraspecific hybrids, three out six crosses displayed advantageous positive SCA effect with range of -1.77 to 1.46 . Desirable positive value was exhibited by $\mathrm{N}$ $502 \times \mathrm{N}-532$ (1.46) followed by $\mathrm{N}-510 \times \mathrm{N}-$ 532 (1.36), and $\mathrm{N}-531 \times \mathrm{N}-532$ (0.18) while remaining three intraspecific crosses showed negative SCA effect for the said trait. For oil content, N-547 x J-109 (1.81), N-502 x N532 (1.46), and N-533 x C-118 (1.38) was found superior for SCA effects among all other $\mathrm{F}_{1}$ hybrids and were considered as best specific combiners for this trait.

\section{Protein content (\%)}

Analysis of variance of protein content showed significant genetic differences $(\mathrm{p}<0.01)$ among parents and their respective $\mathrm{F}_{1}$ hybrids (Table 3). Overall parental and $\mathrm{F}_{1}$ mean was $25.3 \%$ and $25.4 \%$ respectively (Table 4). In protein content, three out of six lines showed positive GCA values. GCA value for lines was in a range of -0.77 to 0.62 . The three lines which showed positive GCA values were $\mathrm{N}-531(0.62)$ and $\mathrm{N}-510(0.46)$, 
and N-547 (0.19), while N-502 (-0.77), N533 (-0.41), and $\mathrm{N}-514$ (-0.09) exhibited negative GCA value for protein content. For testers, GCA values for the said trait ranged from -0.09 to 0.14 , where maximum positive value was displayed by J-119. GCA effects of two testers N-532 (-0.05) and C-118 (-0.09) were negative (Table 5). Nine out of eighteen $\mathrm{F}_{1}$ hybrids exhibited desirable negative SCA effect for protein content, while remaining nine hybrids showed positive value for this trait. Overall, SCA value among all the crosses ranged from -1.20 to 1.43 , where the maximum positive and the maximum negative values were shown by an interspecific and intraspecific cross respectively. SCA effect amid interspecific crosses ranged from -0.73 to 1.43 , where desirable negative value was noticed in $\mathrm{N}$ 533 x J-109 while positive value was shown by N-547 x C-118 (Table 6). Four out of six interspecific crosses of $B$. napus and $B$. campestris displayed desirable negative SCA effect, while remaining two showed positive SCA value which was undesirable in this case. Desirable SCA values for protein

Table 3. Mean squares for biochemical traits of line $x$ tester analysis in Brassica genotypes

\begin{tabular}{|c|c|c|c|c|c|c|c|c|}
\hline $\begin{array}{c}\text { Source of } \\
\text { variation }\end{array}$ & Df & $\begin{array}{c}\text { Oil } \\
\text { content }\end{array}$ & $\begin{array}{c}\text { Protein } \\
\text { content }\end{array}$ & $\begin{array}{c}\text { Glucosinolate } \\
\text { content }\end{array}$ & $\begin{array}{c}\text { Oleic } \\
\text { acid }\end{array}$ & $\begin{array}{c}\text { Linolenic } \\
\text { acid }\end{array}$ & $\begin{array}{c}\text { Erucic } \\
\text { acid }\end{array}$ & $\begin{array}{c}\text { Oil yield } \\
\text { plant }\end{array}$ \\
\hline \multicolumn{8}{|c|}{ Analysis of variance } \\
\hline Replications & 2 & 84.68 & 56.67 & 61.00 & 28.26 & 0.43 & 330.43 & 5.63 \\
\hline Genotypes & 26 & $36.69^{* *}$ & $11.46^{* *}$ & $1240.36^{* *}$ & $46.15^{* *}$ & $4.59^{* *}$ & $607.01^{* *}$ & $36.24 * *$ \\
\hline \multicolumn{7}{|c|}{ ANOVA for Line x Tester Analysis } \\
\hline Parents (P) & 8 & 14.60 & 5.69 & 1846.39 & 64.38 & 4.73 & 673.94 & 20.32 \\
\hline Crosses (C) & 17 & $10.52^{* *}$ & $1.92^{* *}$ & $95.54 * *$ & $6.12^{* *}$ & $0.51^{* *}$ & $67.96^{* *}$ & $6.47^{* *}$ \\
\hline P vs C & 1 & 658.26 & 219.79 & 15853.88 & 580.97 & 72.91 & 9235.30 & 669.62 \\
\hline Lines & 5 & $4.57 \mathrm{~ns}$ & $2.53 \mathrm{~ns}$ & $101.18 \mathrm{~ns}$ & $6.47 \mathrm{~ns}$ & $0.42 \mathrm{~ns}$ & $60.75 \mathrm{~ns}$ & $4.08 \mathrm{~ns}$ \\
\hline Testers & 2 & $47.87 *$ & $0.28 \mathrm{~ns}$ & $156.96 \mathrm{~ns}$ & $16.70^{*}$ & $0.41^{*}$ & $269.71 \mathrm{~ns}$ & $22.43^{*}$ \\
\hline Line x Testers & 10 & $6.02 *$ & $1.94 *$ & $80.44 * *$ & $3.82 * *$ & $0.58 * *$ & $31.21 * *$ & $4.48 * *$ \\
\hline Error & 52 & 2.97 & 0.66 & 7.65 & 1.34 & 0.03 & 15.39 & 1.84 \\
\hline CV (\%) & - & 3.82 & 3.21 & 3.59 & 2.44 & 1.71 & 8.97 & 11.3 \\
\hline
\end{tabular}

$*, * *=$ significant at 1 and $5 \%$ probability level respectively, ns $=$ non-significant

Glucosinolate contents $\left(\boldsymbol{\mu M} \mathbf{g}^{-1}\right)$

Analysis of variance of glucosinolate contents showed significant genetic differences $(\mathrm{p}<0.01)$ among parents and their content demonstrated by cross $\mathrm{N}-514$ x C118 (-0.58), N-531 x C-118 (-0.47), N-502 x C-118 (-0.28), and N-510 x C-118 (-0.24). Three out of six interspecific crosses of $B$. napus and $B$. juncea displayed desirable negative SCA effect, while remaining three showed positive SCA value which is undesirable in this case. Desirable SCA values for protein content was demonstrated by crosses N-533 x J-109 (-0.73), N-510 x J109 (-0.37), and N-547 x J-109 (-0.23). Interspecific cross between $B$. napus and $B$. campestris showed most desirable SCA effect. (Table 6). Amid intraspecific hybrids, two out of six displayed negative SCA effect while remaining intraspecific crosses exhibited SCA value in a positive direction. SCA effect ranged from -1.20 to 0.60 among intraspecific crosses. The maximum negative SCA effects were infatuated by $\mathrm{F}_{1}$ hybrids i.e. $\mathrm{N}-547$ x N-532 (-1.20), N-502 x N-532 (0.32 ). For protein content, N-547 x N-532 ($1.20), \mathrm{N}-533 \times \mathrm{J}-109$ (-0.73), and N-514 x C$118(-0.58)$ proved to be the best specific combiners. 
-6.32 to 3.25 . Four out of six lines showed positive GCA effects, while remaining two were in negative direction. Highest positive GCA effects was displayed by N-531 followed by N-533 (1.87), N-510 (0.47), N$510(0.01)$ and two of them, N-547 (-6.32), and N-514 (-0.27) exhibited GCA effects in the negative direction. GCA effect for testers varied from -2.81 to 3.07 , where $\mathrm{C}-118$ had highest positive value while tester $\mathrm{N}-532$ (2.81), and J-109 (-0.26) exhibited negative GCA value for plant height (Table 5). Nine out of eighteen $F_{1}$ hybrids showed negative SCA effect varying from -0.39 to -5.06 , while remaining eight hybrids exhibited SCA effects in a positive direction with range of 0.28 to 7.39 . Overall, the maximum positive and the maximum negative SCA effect was displayed by N-510 x J-109 (7.39) and N-502 x N-532 (-5.06) (Table 6). Furthermore, results regarding SCA effect for interspecific hybrids of $B$. napus and $B$. campestris showed that two crosses exhibited desirable negative value, while four crosses showed positive SCA effect for this trait having range of -4.74 to 5.45. The maximum negative SCA effect was recorded for $\mathrm{N}-533 \times \mathrm{C}-118$ followed by $\mathrm{N}-510 \times \mathrm{C}-118(-4.34)$, while the maximum positive $\mathrm{SCA}$ effect was noticed in $\mathrm{N}-510$ x J-109 (7.39) followed by N-502 x C118 (5.45). Results regarding SCA effect for interspecific hybrids of $B$. napus and $B$. juncea showed that four out of six crosses exhibited desirable negative value while two crosses showed positive SCA effect for this trait having range of -4.39 to 7.39 . The maximum negative SCA effect was recorded for N-531 x J-109 (-4.39), N-547 x J-109 (2.75), N-533 x J-109 (-2.07), and N-502 x J109 (-0.39) while the maximum positive SCA effect was noticed in N-510 x J-109 (7.39). SCA effect among intraspecific hybrids ranged from -5.06 to 6.81 , where highest negative value was recorded for $\mathrm{N}-502 \times \mathrm{N}$ 532 followed by $\mathrm{N}-510 \times \mathrm{N}-532$ (-3.05), and $\mathrm{N}-514 \times \mathrm{N}-532$ (-2.87), while undesirable positive value was shown by $\mathrm{N}-533 \times \mathrm{N}-532$ followed by N-547 x N-532 (2.47), and N$531 \times \mathrm{N}-532$ (1.70). Three out of six intraspecific crosses exhibited negative SCA effect, while remaining crosses showed SCA effect in a positive direction. On the whole, $\mathrm{N}-502$ x N-532, N-533 x C-118, and N-531 x $\mathrm{J}-109$ were found as best specific combiners for the said trait.

\section{Oleic acid content (\%)}

Analysis of variance of oleic Acid contents showed significant genetic differences $(p<0.01)$ among parents and their respective $\mathrm{F}_{1}$ hybrids (Table 3). Overall parental and $\mathrm{F}_{1}$ mean was $47.3 \%$ and $47.3 \%$ respectively (Table 4). In case of oleic acid, the line GCA ranged from -0.68 to 1.47 . The tester GCA range was from -0.85to 1.05. Amid lines, maximum positive GCA value was given by $\mathrm{N}-533$ followed by N-547 (0.58) while maximum negative GCA value was recorded for $\mathrm{N}-531$ followed by N-514 (-0.47), N-510 (-0.46), and N-502 (-0.43). Amongst testers, the only positive GCA value was exhibited by N-532 (1.05) while other two testers showed negative GCA value (Table 5). For oleic acid, overall SCA range (0.11 to 1.52$)$ of positive nature was observed in nine $F_{1}$ crosses, while negative SCA range (-0.01 to 1.73) of was noted for nine $F_{1}$ crosses. Maximum positive and negative SCA value was shown by $\mathrm{N}-533$ x C-118 and N-533 x J109 (Table 6). Amid interspecific hybrids of B. napus and B. campestris, three out of six crosses showed desirable positive SCA effect while remaining crosses showed SCA effect in a negative direction. SCA effect ranged from -1.64 to 1.52 , where the maximum positive values were observed in $\mathrm{N}-533 \times \mathrm{C}$ 118 followed by $\mathrm{N}-514$ x C-118 (0.50), while undesirable negative value was noticed in $\mathrm{N}$ 502 x C-118 (-1.64). Amid interspecific hybrids of $B$. napus and $B$. juncea, three out of six crosses showed desirable positive SCA effect, while remaining crosses showed SCA effect in a negative direction. SCA effect 
ranged from -1.73 to 1.02 , where maximum positive values were observed in N-531 x C109 followed by N-502 x J-109 (0.80), while undesirable negative value was noticed in $\mathrm{N}$ 533 x J-109 (-1.73). SCA effect among intraspecific hybrids ranged from -1.14 to 0.84, where utmost positive SCA effect was displayed by N-502 x N-532 followed by N$510 \times \mathrm{N}-532$ (0.34), and N-533 x N-532 (0.21), while the maximum undesirable negative SCA effect was noticed in N-531 x
$\mathrm{N}-532(-1.14), \mathrm{N}-547 \times \mathrm{N}-532(-0.24)$, and N$514 \times$ N-532 (-0.01). Amongst intraspecific hybrids, three out of six crosses showed positive SCA effect, while remaining hybrids exhibited SCA effect in an opposite direction. On overall basis, N-533 x C-118 (1.52), N$531 \times \mathrm{J}-109$ (-1.02), and N-502 x N-532 (0.84) were found superior for SCA effect and considered as best specific combiners for the oleic acid.

Table 4. Mean performance of parents and their respective $F_{1}$ hybrids for biochemical traits in Brassica genotypes

\begin{tabular}{|c|c|c|c|c|c|c|c|}
\hline Genotypes & $\begin{array}{c}\text { Oil } \\
\text { content } \\
(\%)\end{array}$ & $\begin{array}{c}\text { Protein } \\
\text { content } \\
(\%)\end{array}$ & $\begin{array}{l}\text { Glucosinolate } \\
\text { content }(\%)\end{array}$ & $\begin{array}{l}\text { Oleic } \\
\text { acid } \\
(\%)\end{array}$ & $\begin{array}{c}\text { Linolenic } \\
\text { acid } \\
(\%)\end{array}$ & $\begin{array}{c}\text { Erucic } \\
\text { acid } \\
\text { content } \\
(\%)\end{array}$ & $\begin{array}{c}\text { Oil yield } \\
\text { plant }^{-1} \\
\text { (g) }\end{array}$ \\
\hline \multicolumn{8}{|c|}{ Lines } \\
\hline $\mathrm{N}-502$ & 42.7 & 27.2 & 29.8 & 47.5 & 8.8 & 45.6 & 13.66 \\
\hline N-510 & 48.8 & 23.7 & 67.6 & 52.3 & 7.9 & 33.5 & 13.49 \\
\hline $\mathrm{N}-514$ & 43.6 & 25.9 & 87.0 & 44.3 & 9.7 & 46.5 & 10.22 \\
\hline N-531 & 48.1 & 24.9 & 73.2 & 54.3 & 11.5 & 27.6 & 16.83 \\
\hline N-533 & 44.1 & 26.0 & 89.3 & 46.5 & 8.9 & 25.4 & 15.25 \\
\hline $\mathrm{N}-547$ & 43.1 & 23.2 & 41.3 & 45 & 7.4 & 20.2 & 14.31 \\
\hline Mean (Lines) & 45.1 & 25.1 & 64.7 & 48.3 & 9.0 & 33.1 & 14.0 \\
\hline \multicolumn{8}{|c|}{ Testers } \\
\hline C-118 & 46.0 & 25.3 & 87.3 & 48.7 & 9.6 & 58.6 & 9.27 \\
\hline N-532 & 46.1 & 24.3 & 43.3 & 49.6 & 7.7 & 21.3 & 12.48 \\
\hline J-109 & 43.9 & 26.9 & 98.5 & 37.3 & 9.1 & 57.1 & 9.76 \\
\hline $\begin{array}{c}\text { Mean } \\
\text { (Testers) }\end{array}$ & 45.3 & 25.5 & 76.4 & 45.2 & 8.8 & 45.7 & 10.50 \\
\hline $\begin{array}{c}\text { Parental } \\
\text { Mean }\end{array}$ & 45.2 & 25.3 & 68.6 & 47.3 & 8.9 & 37.3 & 12.80 \\
\hline \multicolumn{8}{|c|}{$F_{1}$ hybrids (Line $x$ Tester) } \\
\hline $\begin{array}{c}\text { N-547 x C- } \\
118\end{array}$ & 44.5 & 28.2 & 72.3 & 47.6 & 8.3 & 55.2 & 10.34 \\
\hline $\begin{array}{c}\text { N-531 x C- } \\
118 \\
\end{array}$ & 42.5 & 25.7 & 108.2 & 44.7 & 9.7 & 57.6 & 6.66 \\
\hline $\begin{array}{c}\text { N-533 x C- } \\
118\end{array}$ & 47.6 & 24.4 & 81.8 & 53.2 & 10.8 & 58.8 & 12.33 \\
\hline $\begin{array}{c}\text { N-514 x C- } \\
118\end{array}$ & 45.2 & 23.2 & 91.6 & 46.5 & 7.1 & 53.8 & 8.67 \\
\hline $\begin{array}{c}\text { N-510 x C- } \\
118 \\
\end{array}$ & 43.4 & 25.9 & 81.8 & 44.1 & 9.4 & 56.9 & 7.04 \\
\hline $\begin{array}{c}\mathrm{N}-502 \times \mathrm{C}- \\
118\end{array}$ & 42.1 & 22.1 & 106.8 & 43.4 & 9.4 & 48.6 & 6.25 \\
\hline Mean & 44.2 & 24.9 & 90.4 & 46.6 & 9.1 & 55.1 & 8.54 \\
\hline $\mathrm{N}-547 \times \mathrm{J}-109$ & 44.2 & 25.8 & 53.2 & 47.5 & 8 & 52.8 & 6.91 \\
\hline $\mathrm{N}-531 \times \mathrm{J}-109$ & 41.2 & 29.0 & 77.0 & 45.5 & 10 & 56.4 & 9.47 \\
\hline
\end{tabular}




\begin{tabular}{|c|c|c|c|c|c|c|c|}
\hline N-533 x J-109 & 41.2 & 22.5 & 79.8 & 43.7 & 10.5 & 58.8 & 9.94 \\
\hline N-514 x J-109 & 40.9 & 26.7 & 86.2 & 41.6 & 12.3 & 52.3 & 9.52 \\
\hline N-510 x J-109 & 40.5 & 26.2 & 107.0 & 43.0 & 8.8 & 56.1 & 19.43 \\
\hline N-502 x J-109 & 39.1 & 25.4 & 79.3 & 45.6 & 9.8 & 50.2 & 6.71 \\
\hline Mean & $\mathbf{4 1 . 2}$ & $\mathbf{2 5 . 9}$ & $\mathbf{8 0 . 4}$ & $\mathbf{4 4 . 5}$ & $\mathbf{9 . 9}$ & $\mathbf{5 4 . 4}$ & $\mathbf{1 0 . 3 3}$ \\
\hline $\begin{array}{c}\text { N-547 x N- } \\
\mathbf{5 3 2}\end{array}$ & 46.1 & 22.3 & 61.2 & 51.2 & 8.9 & 19.7 & 8.83 \\
\hline $\begin{array}{c}\text { N-531 x N- } \\
\mathbf{5 3 2}\end{array}$ & 47.8 & 27.4 & 87.6 & 49.6 & 10.8 & 41.2 & 13.16 \\
\hline $\begin{array}{c}\text { N-533 x N- } \\
\mathbf{5 3 2}\end{array}$ & 49.6 & 25.9 & 98.8 & 54.1 & 8.8 & 42.1 & 12.14 \\
\hline $\begin{array}{c}\text { N-514 x N- } \\
\mathbf{5 3 2}\end{array}$ & 50.0 & 25.8 & 63.3 & 48.7 & 8.2 & 20.4 & 16.06 \\
\hline $\begin{array}{c}\text { N-510 x N- } \\
\mathbf{5 3 2}\end{array}$ & 51.9 & 28.6 & 68.0 & 49.8 & 9.6 & 25.4 & 11.64 \\
\hline $\begin{array}{c}\text { N-502 x N- } \\
\mathbf{5 3 2}\end{array}$ & 52.1 & 22.1 & $\mathbf{5 7 . 6}$ & 51.2 & 8.4 & 37.6 & 15.47 \\
\hline Mean & $\mathbf{4 9 . 6}$ & $\mathbf{2 5 . 3}$ & $\mathbf{7 2 . 7}$ & $\mathbf{5 0 . 8}$ & $\mathbf{9 . 1}$ & $\mathbf{3 1 . 1}$ & $\mathbf{1 2 . 8 8}$ \\
\hline $\begin{array}{c}\text { Overall F } \\
\text { Mean }\end{array}$ & $\mathbf{4 5 . 0}$ & $\mathbf{2 5 . 4}$ & $\mathbf{8 1 . 2}$ & $\mathbf{4 7 . 3}$ & $\mathbf{9 . 3 8}$ & $\mathbf{4 6 . 9}$ & $\mathbf{1 0 . 5 9}$ \\
\hline LSD(0.01) & $\mathbf{1 . 7 5}$ & $\mathbf{1 . 7 8}$ & $\mathbf{2 . 2 3}$ & $\mathbf{1 . 8 9}$ & $\mathbf{0 . 2 6}$ & $\mathbf{1 . 1 4}$ & $\mathbf{0 . 5 9}$ \\
\hline
\end{tabular}

Table 5. General combining ability effect of lines and testers for biochemical traits in Brassica genotypes

\begin{tabular}{|c|c|c|c|c|c|c|c|}
\hline $\begin{array}{c}\text { Parental } \\
\text { genotypes }\end{array}$ & $\begin{array}{c}\text { Oil } \\
\text { content }\end{array}$ & Protein & Glucosinolates & $\begin{array}{c}\text { Oleic } \\
\text { acid }\end{array}$ & $\begin{array}{c}\text { Linolenic } \\
\text { acid }\end{array}$ & $\begin{array}{c}\text { Erucic } \\
\text { acid }\end{array}$ & $\begin{array}{c}\text { Oil yield } \\
\text { plant }^{-1}\end{array}$ \\
\hline \multicolumn{7}{|c|}{ Lines } \\
\hline $\mathbf{N}-547$ & 0.36 & 0.19 & -6.32 & 0.58 & -0.32 & -1.34 & -1.05 \\
\hline $\mathbf{N}-531$ & -1.01 & 0.62 & 3.25 & -0.68 & 0.26 & 1.87 & -0.24 \\
\hline $\mathbf{N}-533$ & 0.64 & -0.41 & 1.87 & 1.47 & 0.22 & 3.87 & 0.59 \\
\hline $\mathbf{N}-514$ & 0.16 & -0.09 & -0.27 & -0.47 & -0.06 & -0.96 & 0.31 \\
\hline $\mathbf{N}-510$ & 0.61 & 0.46 & 1.47 & -0.46 & -0.04 & 0.11 & 0.74 \\
\hline $\mathbf{N}-502$ & -0.76 & -0.77 & 0.01 & -0.43 & -0.06 & -3.54 & -0.34 \\
\hline & \multicolumn{7}{|c|}{ Testers } \\
\hline $\mathbf{C - 1 1 8}$ & -0.44 & -0.09 & 3.07 & -0.20 & -0.09 & 2.76 & -0.52 \\
\hline $\mathbf{N}-532$ & 1.81 & -0.05 & -2.81 & 1.05 & -0.09 & -4.42 & 0.80 \\
\hline $\mathbf{J}-109$ & -1.36 & 0.14 & -0.26 & -0.85 & 0.17 & 1.66 & -0.05 \\
\hline
\end{tabular}

\section{Linolenic acid (\%)}

Analysis of variance of linolenic acid showed significant genetic differences $(\mathrm{p}<0.01)$ among parents and their respective $F_{1}$ hybrids (Table 3). Grand parental and $F_{1}$ mean was $8.9 \%$ and $9.38 \%$ respectively (Table 4 ). Among six lines, two lines manifested positive GCA effects viz., N-531 (0.26), and $\mathrm{N}-533$ (0.22), and four lines viz., N-547 ($0.32), \mathrm{N}-514(-0.06), \mathrm{N}-502(-0.06)$, and $\mathrm{N}-$
502 (-0.04) showed negative GCA effects for linolenic acid content. Out of three testers, only one demonstrated positive GCA effect viz., J-109 (0.17) whereas two testers showed negative GCA effect (Table 5). Amid all the hybrids, Positive SCA values varied from 0.02 to 0.86 (Table 6 ) which was detected in nine $F_{1}$ hybrids for linolenic acid content, whilst remaining nine hybrids showed negative SCA enormity from -0.02 to -0.61 , 
where maximum positive and negative value was observed in interspecific crosses viz. N$514 \times \mathrm{J}-109$ (0.86), and N-514 x C-118 ($0.61)$. SCA values related to interspecific crosses of $B$. napus and B. campestris ranged from -0.61 to 0.34 , where utmost positive values were observed in $\mathrm{N}-533 \times \mathrm{C}-118$, followed by $\mathrm{N}-502 \times \mathrm{C}-118(0.15)$, while utmost negative SCA effect was noticed in N$514 \times$ C-118 (-0.61). Four out of six interspecific crosses of $B$. napus and $B$. campestris exhibited positive SCA effect, while remaining two displayed SCA effect in opposite direction. SCA values related to interspecific crosses of $B$. napus and $B$. juncea ranged from -0.33 to 0.86 , where utmost positive values were observed in $\mathrm{N}$ 514 x J-109, followed by N-502 x J-109 (0.03) while utmost negative SCA effect were noticed in $\mathrm{N}-510 \times \mathrm{J}-109(-0.33)$, and N-
547 x J-109 (-0.31). Two out of six interspecific crosses of $B$. napus and $B$. juncea exhibited positive SCA effect while remaining four displayed SCA effect in opposite direction. Amongst intraspecific crosses, three out of six crosses showed positive SCA values ranged from 0.20 to 0.30 , where maximum positive SCA effect was noticed in $\mathrm{N}-531 \times \mathrm{N}-532$ (0.30), followed by N-547 x N-532 (0.25), and N$510 \times \mathrm{N}-532$ (0.20). Three intraspecific crosses showed SCA effect in a negative direction viz. N-533 x N-532 (-0.32), N-514 $x \mathrm{~N}-532(-0.25)$, and N-502 x N-532 (-0.18). On the whole intraspecific hybrids ranged from -0.32 to 0.30 . For linolenic acid content, N-514 x J-109 (0.86), N-533 x C-118 (0.34), and $\mathrm{N}-531$ x N-532 (0.30) were the best specific combiners.

Table 6. Specific combining ability effects of (line $x$ tester) for biochemical traits in Brassica genotypes

\begin{tabular}{|c|c|c|c|c|c|c|c|}
\hline F1 hybrids & $\begin{array}{c}\text { Oil } \\
\text { content }\end{array}$ & Protein & GSL & $\begin{array}{l}\text { Oleic } \\
\text { acid }\end{array}$ & $\begin{array}{l}\text { Linolenic } \\
\text { acid }\end{array}$ & $\begin{array}{c}\text { Erucic } \\
\text { acid }\end{array}$ & $\begin{array}{l}\text { Oil yield } \\
\text { plant }^{-1}\end{array}$ \\
\hline N-547 x C-118 & 0.04 & 1.43 & 0.28 & -0.19 & 0.05 & 1.61 & 1.52 \\
\hline N-531 x C-118 & -1.34 & -0.47 & 2.68 & 0.11 & -0.07 & -0.80 & -0.52 \\
\hline $\mathrm{N}-533 \times \mathrm{C}-118$ & 1.38 & 0.13 & -4.74 & 1.52 & 0.34 & -1.94 & 1.32 \\
\hline N-514 x C-118 & 0.39 & -0.58 & 0.67 & 0.50 & -0.61 & 1.83 & -0.40 \\
\hline $\mathrm{N}-510 \times \mathrm{C}-118$ & -0.66 & -0.24 & -4.34 & -0.31 & 0.13 & 0.74 & -1.37 \\
\hline $\mathrm{N}-502 \times \mathrm{C}-118$ & 0.28 & -0.28 & 5.45 & -1.64 & 0.15 & -1.43 & -0.56 \\
\hline N-547 x J-109 & 1.81 & -0.23 & -2.75 & 0.42 & -0.31 & 1.90 & -0.09 \\
\hline N-531 x J-109 & 1.15 & 0.40 & -4.39 & 1.02 & -0.23 & -0.11 & -0.04 \\
\hline N-533 x J-109 & -0.50 & -0.73 & -2.07 & -1.73 & -0.02 & -1.31 & -0.72 \\
\hline N-514 x J-109 & -0.12 & 0.34 & 2.20 & -0.49 & 0.86 & 1.36 & -0.58 \\
\hline $\mathrm{N}-510 \times \mathrm{J}-109$ & -0.70 & -0.37 & 7.39 & -0.03 & -0.33 & 1.85 & 2.30 \\
\hline N-502 x J-109 & -1.64 & 0.59 & -0.39 & 0.80 & 0.03 & -3.70 & -0.87 \\
\hline $\mathrm{N}-547$ x N-532 & -1.77 & -1.20 & 2.47 & -0.24 & 0.25 & -3.51 & -0.30 \\
\hline N-531 x N-532 & 0.18 & 0.06 & 1.70 & -1.14 & 0.30 & 0.91 & 0.33 \\
\hline $\mathrm{N}-533 \times$ N-532 & -0.87 & 0.60 & 6.81 & 0.21 & -0.32 & 3.25 & -0.83 \\
\hline $\mathrm{N}-514 \times$ N-532 & -0.26 & 0.24 & -2.87 & -0.01 & -0.25 & -3.19 & 0.75 \\
\hline $\mathrm{N}-510 \times \mathrm{N}-532$ & 1.36 & 0.62 & -3.05 & 0.34 & 0.20 & -2.59 & -1.15 \\
\hline $\mathrm{N}-502 \times \mathrm{N}-532$ & 1.46 & -0.32 & -5.06 & 0.84 & -0.18 & 5.12 & 1.20 \\
\hline
\end{tabular}




\section{Erucic acid content (\%)}

Analysis of variance of erucic acid showed significant genetic differences $(p<0.01)$ among parents and their respective $F_{1}$ hybrids (Table 3). Grand parental and $F_{1}$ mean was $37.3 \%$ and $46.9 \%$ respectively (Table 4 ). Three out of six lines showed positive GCA effects. N-533 (3.87), N-531 (1.87), and N$510(0.11)$ exhibited GCA effects in the positive direction. On the other hand, N-502 (-3.54), N-547 (-1.34), and N-514 (-0.96) were three lines which depicted GCA effects in negative direction. For testers, GCA effect ranged from -4.42 to 2.76 . Positive GCA value was exhibited by two testers i.e., C-118 (2.76) and J-109 (1.66), while other tester N$532(-4.42)$ revealed negative GCA values (Table 5). For erucic acid content, nine out of eighteen $F_{1}$ hybrids showed enviable negative SCA effects. Overall range of SCA for days to flower initiation among all hybrids was -3.70 to 5.12 , where desirable maximum negative value was exhibited by an interspecific crosses between $B$. napus and $B$. juncea (N-502 x J-109) while maximum positive SCA effect was noticed in an intraspecific cross of B. napus (N-502 x N532) (Table 6). Among interspecific crosses of B. napus and B. campestris, three out of six crosses revealed desirable negative SCA value, while remaining three displayed positive SCA effect. SCA value among interspecific crosses of this group varied from $-1.94(\mathrm{~N}-533 \times \mathrm{C}-118)$ to $1.83(\mathrm{~N}-514 \mathrm{x}$ $\mathrm{C}-118)$. Among interspecific crosses of $B$. napus and $B$. juncea, three out of six crosses revealed desirable negative SCA value while remaining three displayed positive SCA effect. SCA value among interspecific crosses of this group varied from $-3.70(\mathrm{~N}$ $502 \times \mathrm{J}-109)$ to 1.90 (N-547 x J-109). Amid intraspecific crosses, three out of total six crosses showed desirable negative SCA value, while remaining three exhibited positive SCA effect. SCA for intraspecific crosses for the same trait ranged from -3.51 to 5.12 , where most desirable value showed by $\mathrm{N}-547 \times \mathrm{N}-532$, followed by $\mathrm{N}-514$ x N$532(-3.19)$ and $\mathrm{N}-510 \times \mathrm{N}-532(-2.59)$. Overall, N-502 x J-109 (-3.70), N-547 x N532 (-3.51), and N-510 x N-532 (-2.19) were found superior for SCA effect and considered as best specific combiners for the erucic acid content.

Oil yield plant ${ }^{-1}(\mathrm{~g})$

Analysis of variance of oil yield plant ${ }^{-1}$ showed significant genetic differences $(\mathrm{p}<0.01)$ among parents and their respective $F_{1}$ hybrids (Table 3). Grand parental and $F_{1}$ mean was $12.80 \%$ and $10.59 \%$ respectively (Table 4).In oil yield plant ${ }^{-1}$, the lines $\mathrm{N}-510$ (0.74), N-533 (0.59), and N-514 (0.31) excelled all other lines by having highest positive GCA effects, however, other lines showed GCA effect in a negative way. Testers GCA for the said trait was in a range of -0.52 to 0.80 , where maximum positive GCA value was displayed by $\mathrm{N}-532$ while the remaining testers, C-118 (-0.52), and J-109 (0.05 ) exhibited negative GCA effects (Table 5). For oil yield plant ${ }^{-1}$, six out of eighteen $F_{1}$ hybrids showed enviable positive SCA effects. Overall range of SCA for oil yield plant $^{-1}$ among all hybrids was -1.15 to 2.30 , where desirable maximum positive values were exhibited by an interspecific crosses between B. napus and B. juncea (N-510 x J109), while maximum negative SCA effect was also noticed in an interspecific crosses of B. napus and B. campestris (N-510 x C-118) (Table 6). Among interspecific crosses of $B$. napus and B. campestris, two out of six crosses revealed desirable positive SCA value, while remaining four displayed negative SCA effect. SCA values among interspecific crosses of this group varied from -1.37 (N-510 x C-118) to $1.52(\mathrm{~N}-547 \mathrm{x}$ $\mathrm{C}-118)$. Furthermore, desirable positive SCA effects were displayed by $\mathrm{F}_{1}$ crosses viz. N$547 \times \mathrm{C}-118$ (1.52), and $\mathrm{N}-533 \times \mathrm{C}-118$ (1.32). Among interspecific crosses of $B$. napus and $\mathrm{B}$. juncea, one out of six crosses 
revealed desirable positive SCA value while remaining four displayed negative SCA effect. SCA values among interspecific crosses of this group varied from $-0.87(\mathrm{~N}$ $502 \times \mathrm{J}-109)$ to $2.30(\mathrm{~N}-510 \times \mathrm{J}-109)$. Amid intraspecific crosses, only three out of six crosses showed desirable positive SCA value, while remaining three exhibited negative SCA effect. SCA for intraspecific crosses for the same trait ranged from -1.15 to 1.20 , where most desirable value showed by $\mathrm{N}-502$ x N-532, followed by N- N-514 x $\mathrm{N}-532$ (0.75), and N-531 x N-532 (0.33). In general, interspecific hybrids proved to be best specific combiners for oil yield plant ${ }^{-1}$ i.e. N-510 x J-109 (2.30), N-547 x C-118 (1.52), and N-533 x C-118 (1.32).

\section{Discussion}

One of the main objectives of breeding in oil seed Brassica is to produce more oil with desirable acid content viz., oleic acid and linolenic acid content, therefore Brassica lines containing more oil and these useful acids is desirable. Positive GCA and SCA values for oil content, oleic and linolenic acid content is also desirable. In present study, the maximum lines showed positive GCA values for oil content, but exhibited negative values for both oleic and linolenic acid, whereas the maximum crosses showed positive SCA values for the above studied traits. Oil content and one oil quality trait (Linolenic acid content) revealed the maximum SCA mean squares as compared to GCA and were controlled by non-additive type of gene action, while oleic acid manifested maximum GCA mean squares as compared to SCA, and were controlled by additive type of gene action. Our results are contradicted by [20], who found additive gene action for both oil and linolenic acid content and displayed nonadditive type gene action for oleic acid content. Out findings are further opposed by $[21,22]$, who also found additive type of gene action for the oil content.
Glucosinolate and erucic acid are major undesirable components of Brassica seed meal, which make oil unsuitable for human consumption. For GSL and erucic acid, negative GCA and SCA values are desirable. In present study, many lines showed negative GCA, while the maximum crosses also exhibited negative SCA. According to mean squares for combining ability, it is revealed that for both GSL and erucic acid content, mean squares of GCA is greater as compared to SCA, and was controlled by additive type of gene action. Our results are confirmed by the findings of $[20,23]$, who also found same type of gene action for both Erucic and glucosinolate content.

Protein and oil content are inversely related to each other, one increasing at the cost of other. In present study, many lines and crosses exhibited negative GCA and SCA values respectively. However, protein content revealed maximum GCA mean squares as compared to SCA, and was controlled by additive gene action. Our findings are in agreement of [12], who also found additive type of gene action in protein content. Our results are further strengthened by [22], who also found additive type of gene action in protein content.

\section{Conclusion}

The interspecific $\mathrm{F}_{1}$ hybrid $\mathrm{N}-533 \times \mathrm{C}-118$ exhibited the maximum values for oil content, oleic acid content, and oil yield plant $^{-1}$ while intraspecific hybrid, N-510 x N532 were found best for linolenic acid content. Cross combination N-502 x N-532 was best hybrid for oil content. The B. napus line N-533 exhibited desirable GCA effects protein content and oleic acid content, while another napus line N-531 was also found as one of leading general combiner, by showing desirable GCA value for linolenic acid content. Line N-502 was found to be best general combiner for protein and erucic acid content. In testers, N-532 was observed to be best general combiner and exhibited 
desirable GCA values for as many as seven traits, while tester $\mathrm{C}-118$ emerged as best general combiner for important traits. These above best general combiners exhibited stability and showed outstanding contribution in $F_{1}$ crosses for oil quality traits. In general, the $\mathrm{F}_{1}$ hybrid $\mathrm{N}-533$ x C118 and $\mathrm{N}-510$ x J-109 revealed maximum desirable SCA effects for oil yield. Based on the findings of this study, the above mentioned crosses have potential for the improvement of various traits and for the development of elite class found for Brassica's variety.

\section{Authors' contributions}

Conceived and designed the experiments: Farhatullah, Performed the experiments: S Shah, Analyzed the data: A Sohail \& IH Khalil, Contributed reagents/ materials/ analysis tools: T Burni \& F Hadi, Wrote the paper: A Sohail.

\section{References}

1. Sohail A, Shah S, Farhatullah, Shah SMA, Ali S, Izzam A \& Hussain Q (2018). Assessment of genetic variability, heritability and selection response for morph-yield traits in brassica. Pure Appl Biol 7(1): 50-56.

2. ESOP (2016-2017). Economics Survey of Pakistan. Finance Division, Economic Advisor's Wing, Islamabad.

3. Khan, FA, Ali S, Shakeel A, Saeed A \& Abbas $G$ (2016). Genetic variability and genetic advance analysis for some morphological traits in Brassica napus L. J Agric Res 44(2): 83-88.

4. AOCS (2016). World oilseed scenario. American Oil Chemists' Society.

5. Warwick SI, Francis A \& Al-Shehbaz IA (2015). Brassicaceae: species checklist and database on CD-Rom. Pl Syst Evol 259: 249-258.

6. Rich TCG (1991). Crucifers of Great Britain and Ireland. Botanical Society of the British Isles, London. pp 336.
7. Zhou WJ, Zhang GQ, Tuvesson S, Dayteg C \& Gertsson B (2016). Genetic survey of Chinese and Swedish oilseed rape (Brassica napus L.) by simple sequence repeats (SSRs) Genet Resour. Crop Evol 53: 443-447.

8. Rakow G (2014). Species origin and economic importance of Brassica. In: Nagata, T., Lörz,H. \& Widholm, J.M. (Eds) Biotechnology in agriculture and forestry. Springer 54: 3-12.

9. Ananga AO, Cebert E, Soliman K, Kantety R \& Pacumbaba RP (2006). RAPD makers associated with resistance to blackleg disease in brassica species. African J Biotech 5(22): 2041-2048.

10. Khatri A, Khan IA, Siddiqui MA, Raza S \& Nizamani GS (2015). Evaluation of high yielding mutants of Brassica juncea cv. S-9 developed through Gamma rays and EMS. Pak J Bot 37(2): 279-284.

11. Ofori A \& Becker HC (2008). Breeding of Brassica rapa for biogas production: heterosis and combining ability of biomass yield. Bioenerg Res 1: 98-104.

12. Diers BW, McVetty PBE \& Osborn TC (1996). Relationship between heterosis and genetic distance based on restriction fragment length polymorphism markers in oilseed rape (Brassica napus L.). Crop Sci 36: 79-83.

13. Ghosh SK, Gulati SC \& Raman R (2012). Combining ability and heterosis for seed yield and its components in Indian mustard (Brassica juncea (L.) Czern \& Coss). Indian J Genet 62(1): 29-33.

14. Becker HC, Loptien H \& Roebbelen $G$ (1999). Breeding: An overview. In C. Gomez-Campo (ed.) Biology of Brassica coenospecies. Elsevier Science BV, Amsterdam 413-460.

15. Melchinger AE (1999). Genetic diversity and heterosis. In: CG Coors, and S Pandey (Eds), Genetic and Exploitation 
of Heterosis in Crops, $J$ Am Soc Agron 34(1): 99-118.

16. Sprague GF \& Tatum LA (1942). General vs. specific combining ability in single crosses of corn. J Am Soc Agron 34(4): 923-932.

17. Dudley JW \& Moll RH (1969). Interpretation and use of estimates of heritability and genetic variances in plant breeding. Crop Sci 9: 257-262.

18. Marijanovic-Jeromela A, Marinkovic R \& Miladinovic D (2007). Combining abilities of rapeseed (Brassica napus L.) varieties. Genetika 39(1): 53 -62.

19. Singh SP (1973). Heterosis and combining ability estimates in Indian mustard, Brassica juncea (L.) Czern. and coss. Crop Sci 13: 497-499.

20. Turi NA, Raziuddin, Farhatullah, Khan NU, Munir I, Shah AH \& Khan S (2010).
Combining ability analysis in Brassica juncea L. for oil quality traits. African $J$ Biotechnol 9(26): 3998-4002.

21. Singh M, Singh L \& Srivastava SBL (2010). Combining ability analysis in Indian mustard (Brassica juncea L. Czern \& Coss). J. Oilseed Brassica 1(1): 23-27.

22. Qian W, Li Q, Noack J, Sass O, Meng J, Frauen M \& Jung C (2009). Heterotic patterns in rapeseed (Brassica napus L.): II. Crosses between European winter and Chinese semi-winter lines. $\mathrm{Pl}$ Breed 128: 466-470.

23. Sabaghnia N, Dehghani H, Alizadeh B \& Mohghaddam M (2010). Heterosis and combining ability analysis for oil yield and its components in rapeseed. Aust $J$ Crop Sci 4(6): 390-397. 